\title{
The Development of Indonesian Teacher Books Based on Analysis of Contents Contained With Curriculum 2013 to 2016 in Seventh Grade Junior High School Junior High School Negeri 5 Stabat
}

\author{
Tuty Marmiaty \\ Student Postgraduate Program in Indonesia Language \\ Education \\ Universitas Negeri Medan \\ Medan, Indonesia \\ toetyichad@gmail.com
}

\author{
Wisman Hadi \\ Lecturer Postgraduate Program in Indonesia Language \\ Education \\ Universitas Negeri Medan \\ Medan, Indonesia
}

\author{
Malan Lubis \\ Lecturer Postgraduate Program in Indonesia Language Education \\ Universitas Negeri Medan \\ Medan, Indonesia
}

\begin{abstract}
A preliminary review of the ten Teacher Handbooks or Master Books both published by the government and private publishers in some curriculums, using the assessment instrument of BSNP, the researchers found uncertainty in the content and presentation systematics. The empirical data of content analysis in the Indonesian VII Classroom Book of Junior High School revised edition 2016 and 2017, indicates that although the book issued by the government has been assessed feasibility by BSNP but still found the presentation is not in accordance with the curriculum. Understanding and observing the contents of the curriculum needs to be done. The development of the 2013 Curriculum every year is constantly changing. This means that in a short time teachers are required to quickly master the various types of discourse texts and changes that occur each year, in order to immediately teach it to students. The literature study on the study of teacher book development, the result of the continuous discrepancy between Student Book and Master Book and Curriculum 2013. Looking at the above problems, the researcher is very interested to do study on Indonesian Teachers Book. Based on content analysis conducted on teachers books, researchers want to develop Indonesian Class VII Teacher Book at Junior high school Curriculum 2013.
\end{abstract}

Keywords: teacher books, development, content analysise Introduction

\section{INTRODUCTION}

The character formation students nowadays are given special attention in education. Character education is a learning process that aims to develop the character of students from bad to good. Integrating character education in learning Indonesian, especially reading, can be done with reading learning based on active, creative, innovative, effective, and fun learning.
Some channels that can be used to build characters in learning to read is through teaching materials, that is from the additional reading book. Based on the 2013 curriculum, Indonesian language learning is realized through text-based learning. The text developed in this study is a biographical story contain of entrepreneurial values.

The value of entrepreneurship education will motivate students to succeed by working hard. With the biography book stories containing entrepreneurship education values the learners will understand the biographical material and be able to implement the value of the character of the learners at the end of the lesson.

The additional reading book that will be developed in this research is the book of reading skill enrichment. Skill teacher bookss are books that contain material that enriches and enhances the reader's basic skills in order to improve practical and self-directed activities (Book Center 2008: 15). Teacher bookss can also support the development of materials or textbook content. The teacher books function is as a companion of learning.

One of the active activities in language is reading that indicates a person has mastered the language. By reading, students are also trained to be able to argue, such as saying things that are in the minds of students, knowing the content of the writing being read. There are three main objectives of reading learning (Yunus Abidin, 2012: 5), namely (1) enabling students to be able to enjoy reading activities, (2) able to read in the heart with flexible reading speed, (3) and gain sufficient level of understanding reading content.

Reading interesting content certainly adds to student motivation in learning. The values of entrepreneurship 
education are one of interesting educational values. Entrepreneurship is an attitude, a soul and the ability to create something new that is very valuable and useful to itself and others. The values of entrepreneurship conclude commitment, confidence, cooperative, care, creative, challenge, calculation, communications, competitiveness, changes (Rohmat 2013: 7273 in Rohmat 2016).

\section{RESEARCH METHODS}

Methodology in this study is the Borg and Gall Development Model. Teaching Materials developed in this study is a Biography reading book based on the Values of Entrepreneurship Education for Students of Junior High School Class VIII. The research model consists of ten stages, namely (1) research and data collection, (2) data collection, (3) development of product draft, (4) initial field trials, (5) revise test results, (6) Small scale product (7) improvement of product of field test, (8) field implementation test, (9) final product refinement and (10) product dissemination and implementation. Research phase according to Borg and Gall, can be seen in the following figure

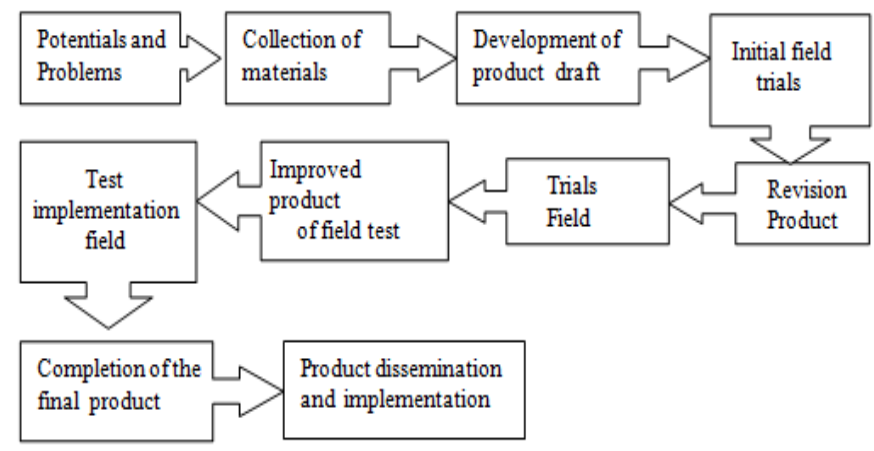

Fig 1. development procedures

This research was conducted on the students of class VIII of Junior high school State 29 Medan located at Letda Sujono Ujung streets number, Benteng Hulu, Tembung, Medan Tembung Medan City, North Sumatera. The developed teaching material was analyzed using the validation of the materials expert team and the instructional material design and the assessment using a rubric developed by the researcher by modifying the expert's opinion. The material criteria are based on the criteria of conformity of biography text materials based on The Values of Entrepreneurship Education and are based on revised 2013 syllabus curriculum 2016.

Design of reading Teacher Books based on Analysis of Contents can be seen in the following figure

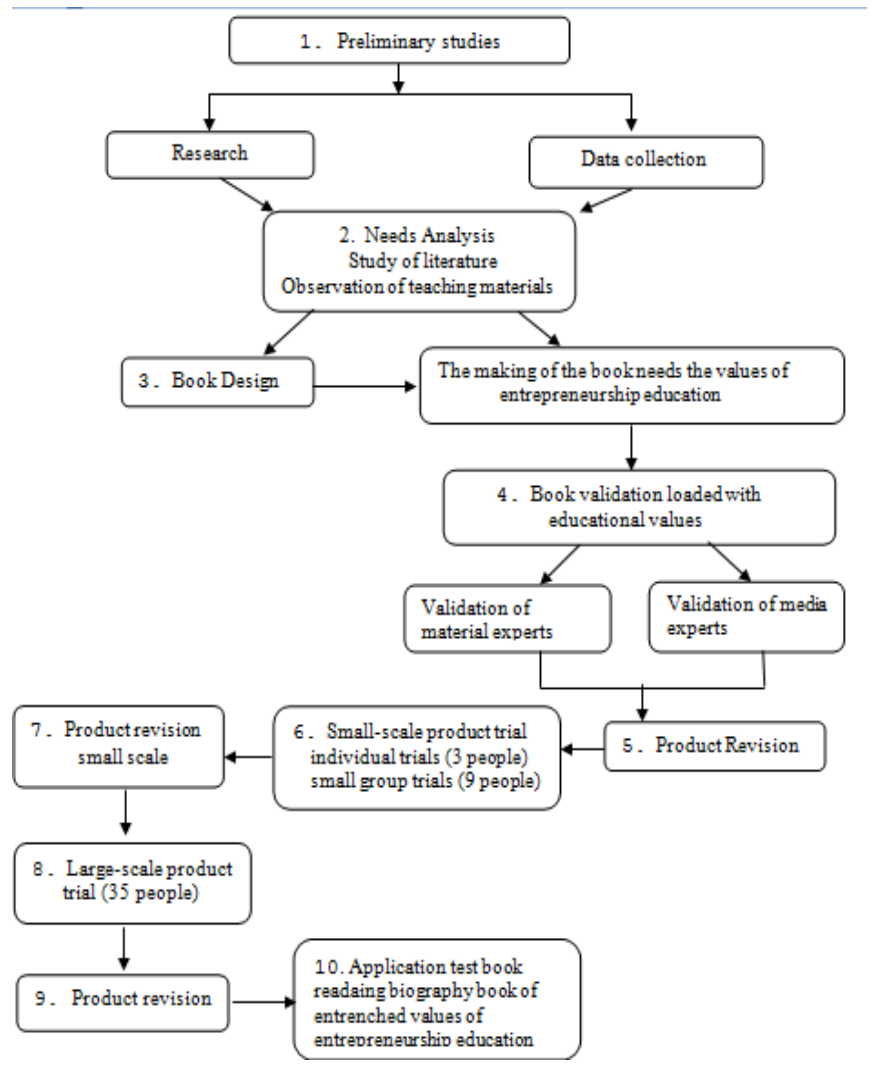

Fig 2. Development procedures for Reading Biography Book

Instruments used in this study to collect data are grou into 2 kinds, namely:

1. Instrument validation team of experts on learning materials writing explanatory text-based troubleshooting methods.

a. The questionnaire validation sheet of the subject matter material

b. Questionnaire design validation master of the questionnaire

2. Instrument responses of students and teachers on teaching materials

a. Individual trial 3 people

b. Trial of small group of 9 people

c. Field trials are limited to 35 people

d. Response Indonesian teacher 2 people

Data analysis techniques conducted in this development study is this data collected through expert validation, questionnaire distributed to students. Assessment instruments for validations and individual trials, small groups and limited field groups are created in the likert scale that has been scored as in the table below. 
TABLE I. CRITERIA ANSWERS INSTRUMENT VALIDATION ITEM WITH LIKERT SCALE (SUGIYONO, 2016: 93)

\begin{tabular}{|l|l|l|}
\hline No. & Answer & Score \\
\hline 1 & Very Good & 4 \\
\hline 2 & Good & 3 \\
\hline 3 & Not Good & 2 \\
\hline 4 & Poorly & 1 \\
\hline
\end{tabular}

Data analysis techniques conducted in this development study is this data collected through expert validation, questionnaire distributed to students.

Then the data is analyzed descriptively quantitative, that is calculated percentage of indicator for each category on instructional material developed.

$\%$ skor $=\frac{\text { number of indicators per category }}{\text { the number of indicators of all categories }} \times 100 \%$

Based on the calculation of the formula above, the figure is generated in percent. The classification of the score is then changed to classification in the form of percentage (Sugiyono, 2011: 118), then interpreted with qualitative sentences.

\section{RESEARCH RESULT}

In the results of research, the researcher describe the results of research development of reading biography books based on entrepreneurial values.

This study begins with a need analysis of 35 students of Junior High School class VIII and two Indonesian language teachers

Based on the data above the subject of research consists of two Indonesian language teachers and 35 students of Junior High School State 29 Medan. A total of 35 subjects of junior high school students are unfamiliar with biography books and require biography books in the learning process.

Students' needs for biography books are evident from observations during the learning process. The need for biographybooks is needed to increase students' knowledge especially in biographical texts with different themes contained in the package book. The theme of entrepreneurship is not contained in the package book, while the theme of entrepreneurship is part of the development of character education in accordance with the curriculum 2013. This is in accordance with the development of scientific foundation in the development of character that is contained in the development of entrepreneurial spirit, one of which is developing education curriculum giving educational content entrepreneurship that can improve understanding of entrepreneurship, foster character, and entrepreneurship skills.

Based on the data Requirement analysis by students obtained the following conclusions:

1. All teachers and students $(100 \%)$ said they were familiar with the explanatory text module based on problem solving.
2. All teachers and students $(100 \%)$ stated that they do not use learning-based explanatory text module based on problem solving in the learning process and never use the media.

3. All teachers and students (100\%) stated needing explanatory text learning module based on problem solving. Data Requirement Analysis can be seen in following tabel

TABLE II DATA REQUIREMENT ANALYSIS

\begin{tabular}{|c|c|c|c|c|c|c|}
\hline \multirow[t]{2}{*}{ No } & \multirow{2}{*}{$\begin{array}{c}\text { Type of } \\
\text { Information }\end{array}$} & \multirow{2}{*}{ Answer } & \multicolumn{4}{|c|}{ Frequency } \\
\hline & & & Teacher & $\%$ & Student & $\%$ \\
\hline \multirow[b]{2}{*}{1.} & \multirow{2}{*}{$\begin{array}{c}\text { Knowing the } \\
\text { biography book } \\
\text { based on the values } \\
\text { of entrepreneurship } \\
\text { education }\end{array}$} & Yes & 2 & $\%$ & 0 & 0 \\
\hline & & No & 0 & 0 & 35 & $100 \%$ \\
\hline \multirow[b]{2}{*}{2.} & \multirow{2}{*}{$\begin{array}{l}\text { Using the } \\
\text { biography books } \\
\text { that contain } \\
\text { entrepreneurial } \\
\text { values in the } \\
\text { leaming process }\end{array}$} & Yes & 0 & 0 & 0 & 0 \\
\hline & & No & 0 & 0 & 0 & 0 \\
\hline \multirow[b]{2}{*}{3.} & \multirow{2}{*}{$\begin{array}{l}\text { Requires the } \\
\text { biography books } \\
\text { that contain } \\
\text { entrepreneurial } \\
\text { values in the } \\
\text { leaming process }\end{array}$} & Yes & 2 & $100 \%$ & 35 & $100 \%$ \\
\hline & & No & 0 & 0 & 0 & 0 \\
\hline
\end{tabular}

The development of this biography book comprises four KDs contained in the biographical text material. This teacher books is designed to be varied, innovative, so it does not seem monotonous. This biography book provides various forms of color, photographs of entrepreneurial figures, illustrations that are well arranged and necessary.

Based on the validation assessment of the result test by the expert of entrepreneurship and language by using the formula of the total value obtained divided by the maximum value amount then multiplied hundred percent.

The validation results of the design experts, in the form of scoring scores on the learning component of biography text on The Values of Entrepreneurship Education, can be known through the appraisal done by the design expert from the quality aspect of the learning module that the aspect of the feasibility of grading is considered "Very good" with the percentage of scores for the validation score from design expert is $89 \%$.

The validation result from the material expert, in the form of scoring score on learning component of material complete content, can be known through the assessment done by the material expert from the quality aspect of the reading book biography which includes the quality of the content feasibility, feasibility of presentation, language feasibility, and feasibility is rated "very good" with the percentage of scores for validation scores from material experts is $93.05 \%$.

The validation reslut from material expert, in the from of scoring score on the economic entrepreneurship, can be know through the assessment done by book biography which includes the quality of the values of entrepreneurship education is rated "very good" with the percentage of scores 
for validation scores from material expert is $95 \%$ and the quality of languange is rated "very good" with the percentage of score for validation scores from material expert is $97 \%$.

The validation is also done by Indonesian language teachers who assess the feasibility of reading book biography when used in learning. Validation results are $92.4 \%$ with "very good" criteria.

Data Recap validation can be seen in following table

TABLE III RECAP RESULT OF EXPERT TEST VALIDATION OF MATERIAL AND DESIGN

\begin{tabular}{|c|c|c|c|c|}
\hline $\begin{array}{c}\text { The assessed } \\
\text { component }\end{array}$ & $\begin{array}{c}\text { The Total } \\
\text { Component }\end{array}$ & $\begin{array}{c}\text { The } \\
\text { total } \\
\text { score }\end{array}$ & Average & Criteria \\
\hline $\begin{array}{c}\text { Material } \\
\text { Complete Content }\end{array}$ & 18 & 134 & 93,05 & $\begin{array}{c}\text { Very } \\
\text { good }\end{array}$ \\
\hline Language & 17 & 132 & 97 & $\begin{array}{c}\text { Very } \\
\text { good }\end{array}$ \\
\hline $\begin{array}{c}\text { Economics } \\
\text { (Entrepreneurship) }\end{array}$ & 18 & 137 & 95 & $\begin{array}{c}\text { Very } \\
\text { good }\end{array}$ \\
\hline $\begin{array}{c}\text { Design } \\
\text { Leaming Design }\end{array}$ & 28 & 201 & 89 & $\begin{array}{c}\text { Very } \\
\text { good }\end{array}$ \\
\hline
\end{tabular}

Validation is also done by individual test in $(90,13 \%)$ with very good criteria, small group test $(88 \%)$ with very good criteria and last assessment of field test with very good criteria (95\%), result of effectively test to student studying using learning based module problem solving is indicated by the results of data processing obtained value "t", then matched with the table at a significant level of $5 \%=1.66$. This proves that $\mathrm{t}$ count $<\mathrm{t}$ table is $1.66<4.07$. Thus, it is concluded that the development of instructional materials in the form of reading book biography on biography text is very feasible, easy and effective to used on learn in junior high school class VIII.

\section{CONCLUSION}

Reading biography book based on values of entrepreneurship education improve student learning outcomes. Some conclusions in this study are as follows. The result of requirement analysis from 35 junior high school students VIII Junior High School State 29 Medan as much as $100 \%$ have not recognize biography book and need biography book in process of learning. Thus the biography book is indispensable in the learning process.

Product development in this research in the form of biography book is Reading Biography Book based on The Value of Entrepreneurship Education For Students of Junior High School Class VIII. This book consists of three parts, namely (1) The beginning of the book covering book covers, preface, manual use of books (for teachers and students), and table of contents; (2) the contents of the book consists of ten thematic chapters along with their summary and training, (3) cover section contains bibliography. This biography book development product has gone through a series of processes in line with the development stages of Borg and Gall. The book also has been through a limited field trial and effectiveness in school reading skills.

The developing of this reading book biography is a programmable development in a systematic sequence and meets the characteristics to support students in learning. The last test subject of two Indonesian subject matter experts, two design instructional experts, three students for individual testing, nine students for small group test and thirty-two students for field test. Data about the quality of this development product were collected by questionnaire with the result of the research showed that the experimental material was very good (95\%), the test of the very good category learning to design expert (89\%), very good quality individual test $(90,13 \%)$, very good small group test $(88 \%)$ and last assessment of field test with very good quality (95\%), result of effectively test to student learning to use problem-based learning module is shown with result of data processing obtained value " $t$ ", then matched with table at significant level $5 \%=1.66$. This proves that $\mathrm{t}$ count $<\mathrm{t}$ table is $1.66<4.07$. Thus, it was concluded that the developing of Reading Book Biography in the form learning text biography of Junior High School Class VIII.

\section{REFERENCES}

[1] Abidin, Yunus. 2012. Pembelajaran Membaca Berbasis Pendidikan Karakter. Bandung: Refika Aditama.

[2] Benninga, Jacques S., Berkowitz, Marvin W., Kuehn, Phyllis., Smith, Karen. 2003. The Relationship of Character Education Implementation and Academic Achievement in Elementary Schools. Journal of Research in Character Education, 1 (1): 19-32

[3] Depdiknas. 2006. Pedoman Memilih dan Menyusun Buku Pengayaan. Jakarta:Depdiknas.

[4] Lee, Sang M., Chang, Daesung., Bae-Lim, Seong. 2005. Impact of Entrepreneurship Education: A Comparative Study of The U.S. and Korea. International Entrepreneurship and Management Journal, 1 (1): 27-43.

[5] Prastowo, Andi. 2015. Panduan Kreatif Membuat Bahan Ajar Inovatif. Jogjakarta: Diva Press.

[6] Rohmat. 2016. Penguatan Nilai-Nilai Kewirausahaan dan Pendidikan Karakter Bagi Mahasiswa PAI IAIN Surakarta. Shahih, 1(2): 180-183.

[7] Sugiyono. 2016. Metode Penelitian Kuantitatif, Kualitatif dan $R \& D$. Bandung: Alfabeta. 